\title{
SUPPLY CHAIN DESIGN: SOME CRITICAL QUESTIONS
}

\author{
JD NEL* \\ JA BADENHORST-WEISS** \\ *neljd@unisa.ac.za \\ **badenja@unisa.ac.za \\ Department of Business Management \\ University of South Africa (Unisa)
}

South Africa

\begin{abstract}
Effective supply chain management (SCM) requires organisations to work together in order to satisfy the needs of their end customers. Since organisations have to determine which processes and relationships will best achieve this aim, the design of their supply chains is important. Supply chain design thus forms an integral part of SCM and embodies the supply chain's structure. Unfortunately, too many organisations allow the design of their supply chain to evolve into its current form instead of planning their supply chain design (SCD) efforts. The literature is vague on what SCD efforts constitute. This article consists of a comprehensive literature study in which an effort was made to bring more clarity on exactly what purposeful SCD efforts consist of, and some key questions were formulated that organisations could use as a guide in their SCD practices. From these critical questions a conceptual framework has been developed that can be used to determine whether organisations' SCD practices are aligned with organisational objectives. The conceptual framework was tested at two South African organisations to determine if it indeed can be be used to analyse the SCD practices of organisations.
\end{abstract}

\section{INTRODUCTION}

The ability to design an effective supply chain is an important core capability of an organisation because it enables or limits the organisation's competitiveness. As competition shifts from competition between organisations towards competition between supply chains, supply chain design (SCD) will become a key source of competitive advantage and will be a critical factor in determining the efficiency and effectiveness of a supply chain (Reeve \& Srinivasan, 2005: 50; Sezen, 2008: 234). Decisions regarding the SCD are therefore crucial in an organisation (Santoso, Ahmed, Goetschalckx \& Shapiro, 2004: 96). However, even though the strategic role of effective SCD has been well recognised by both academics and practitioners (Pangburn \& Stavrulaki, 2005: 209), the practice of designing supply chains is relatively new because historically the design of supply chains has evolved in response to changes in the business environment (Fawcett, Ellram \& Ogden, 2007: 222) rather than through conscious efforts to design the supply chain. 
A supply chain includes all those parties involved both directly and indirectly in producing products through all the different input, conversion and output stages across various processes and relationships (Lysons \& Farrington, 2006: 91, 92; Chopra \& Meindl, 2007: 3; Baily, Farmer, Crocker, Jessop \& Jones, 2008: 66). Supply chains are not new - they are (and always were) omnipresent (Mentzer, 2001: 7; Bozarth \& Handfield, 2006: 8; Gattorna 2006: 2). All organisations form part of a chain of organisations that begins with a source of materials (suppliers) being supplied and ends with the consumption of a product by customers (buyers) (Handfield \& Nichols, 1999: 5; Hines, 2004: xi; Lambert, 2006: 8; Fawcett, et al. 2007: 11). Each organisation has a role to play in supply chains (Hines, 2004: xi; Hugos, 2006: 2) and all products reach customers via some type of supply chain (Wisner, Leong \& Tan, 2005: 6).

Decisions made within supply chains play a significant role in the success or failure of an organisation (Chopra \& Meindl, 2007: 8; Jacobs, Chase \& Aquilano, 2009: 355). Therefore, the management of the supply chain has become one of the key issues for many organisations, especially in today's turbulent business environment (Nunlee, Qualls \& Rosa, 2000: 354; Mentzer, 2001: 8; Burt, Dobler \& Starling, 2003: 7; Wisner, Leong \& Tan, 2005: 21; Storey, Emberson, Godsell \& Harrison, 2006: 769; Cagliano, Caniato \& Spina, 2006: 282; Matopoulos, Vlachopoulou, Manthou \& Manos, 2007: 177; Kumar, Ozdamar \& Zhang, 2008: 95). Supply chain management (SCM) is a philosophy that has developed in response to changes in the business environment to bridge the new challenges faced by organisations by integrating all the linkages between organisations, their suppliers and their customers into a seamless unit (Hugo, Badenhorst-Weiss \& Van Biljon, 2004: 10).

Essentially, SCM implies integration between supply chain members across key business processes and relationships (Handfield \& Nichols, 2002: 4; Sundaram \& Mehta, 2002: 537; Wisner et al., 2005: 8; Bozarth \& Handfield, 2006: 8; Cagliano et al., 2006: 283; Kim, 2006: 1087; Lambert, 2006: 1; Magnan \& Fawcett, 2006: 346; Fabbe-Costes \& Jahre, 2007: 836; Fawcett et al., 2007: 8). It is therefore important to structure the supply chain correctly and decide what the supply chain's configuration will be. The right members of the supply chain and the tasks that each should perform, as well as how resources will be allocated between supply chain members and what processes each stage will perform, have to be determined (Chopra \& Meindl, 2007: 9; Fawcett et al., 2007: 216). This is done through SCD, which can be regarded as determining how to structure a supply chain as well as all the required components of the supply chain (Persson \& Olhager, 2002: 244; Sharifi, Ismail \& Reid, 2006: 1083, 1084; Saxton, 2006: 244). Designing a supply chain entails identifying and bringing together a group of organisations with competencies that complement each other (Fawcett et al., 2007: 494).

SCD is a complex task which involves aligning the capabilities of the supply chain with customer needs, thus creating value for the end customer and profitability for all supply 
chain partners (Fawcett et al., 2007: 216). SCD forms an integral part of SCM (Santoso et al., 2004: 96) and has become a major challenge for organisations (Shen \& Daskin, 2005: 188). The role of SCD is to provide an optimal platform for efficient and effective SCM (Sharifi et al., 2006: 1083, 1084).

It is generally accepted that supply chain performance is influenced by the supply chain's structure (Moon, 2004: 20). It is also understood that changes in the structural design of the supply chain may improve the performance of the supply chain (Persson \& Olhager, 2002: 231). But the lack of a formal supply chain design can lead to a dysfunctional supply chain when it comes to achieving goals for growth and profits (Ayers, 2006: 56). If organisations do not design their supply chains and instead allow their supply chains merely to evolve based on a series of processes and choices that are made independently, the organisations can expect lower than optimal performance (Fawcett et al., 2007: 216, 217).

The major challenge in evaluating the possible improvements of supply chain results lies in the complex structure of the supply chain (Reiner \& Trcka, 2003: 219). An analysis of the supply chain may be an organisation's first step to improving performance (Reid \& Sanders, 2007: 124). Understanding the components of SCD can enable organisations to design their supply chains appropriately.

The purpose of this article is to report on an extensive exploratory literature study on the components of SCD and to identify the key questions that will be used to develop a framework that can assist organisations with their SCD practices. This conceptual framework may be used to determine whether the organisation's SCD is aligned with organisational objectives. The conceptual framework needs to be developed further and tested empirically to validate the instrument.

\section{THE ELEMENTS OF SUPPLY CHAIN DESIGN}

A supply chain can be defined as consisting of a set of at least three organisations directly linked by the necessary supply chain activities (or supply chain flows) between an organisation, a supplier to the organisation and a customer of the organisation (Mentzer, 2004: 4; Taylor, 2004: 26; Monczka, Trent \& Handfield, 2005: 9). Although this definition of a supply chain implies only three organisations, supply chains are not always quite so simple. A supply chain usually consists of a large number of different configurations between various organisations that form part of the supply chain (Waters, 2003: 10).

Essentially, three primary supply chain flows can be identified in any supply chain, namely information flows, product (or service) flows and finance flows. Information flows can also be termed demand flows and product flows can be termed supply flows (Taylor, 2004: 26; Lambert, 2006: 14). Demand flows up the chain in the form of orders and triggers the 
movement of supply through shipments back down the chain. As products reach customers, finances flow up the supply chain through payments and compensate suppliers for their products (Taylor, 2004: 26). Demand provides the impetus for the other two flows, which means that supply chains are customer-driven (Halldórsson, Kotzab, Mikkola \& Skjǿtt-Larsen, 2005: 37; Hines, 2004: 123). It is from this viewpoint that supply chains have to be designed. The needs of end customers must be understood. The key to managing the flow of products lies in synchronising all three supply chain flows (Taylor, 2004: 26) so that the entire chain of business activities from raw material through to the final point of consumption can be effectively managed to deliver the end customers' value requirements (Zokaei \& Hines, 2007: 223).

With this as background, three broad phases of SCD were identified from a literature study (Taylor, 2004; Fawcett et al., 2007; Christopher, 2005; Sharifi et al., 2006). First, supply chains must understand the nature of the needs of their end customers (Taylor, 2004: 259) and how these needs can be met by some value proposition (Christopher, 2005: 57). Each organisation must know how it can contribute value to meet the demands of the end customers of its supply chain (Christopher, 2005: 57; Fawcett et al., 2007: 222). Secondly, organisations must select a supply chain strategy to be able to deliver value to their end customers (Taylor, 2004: 279). Thirdly, once a supply chain strategy has been selected, the supply chain structure needs to be configured (Sharifi et al., 2006: 1078; Fawcett et al., 2007: 222). This includes deciding on supply chain partners, assigning roles and responsibilities to each of the supply chain members, deciding how supply chain drivers should be utilised and establishing key performance indicators (KPIs). This third phase will be referred to as scoping the supply chain structure (Taylor, 2004: 284; Fawcett et al., 2007: 335). Phases two and three have to be aligned towards meeting the first phase, which is meeting the end customers' needs (Sharifi et al., 2006: 1078). These three phases are illustrated in Figure 1. Each of the elements of the three phases will be addressed.

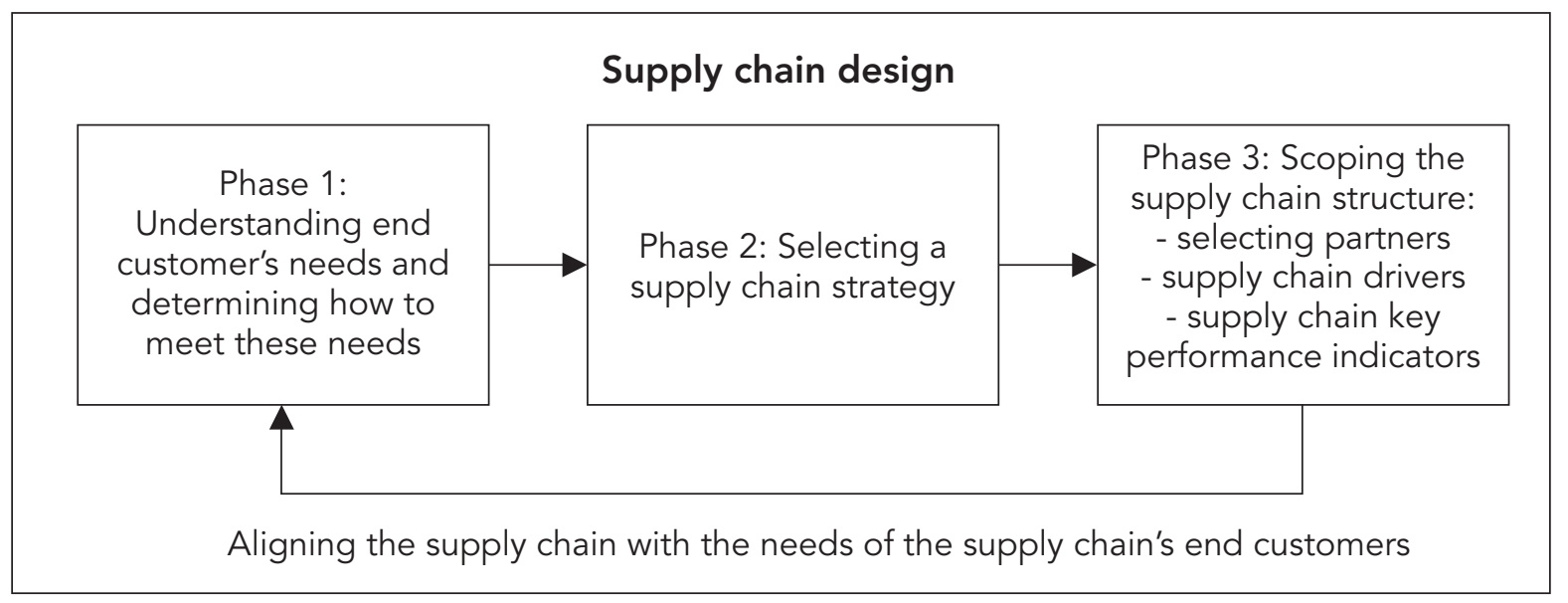

Figure 1: The three phases of supply chain design (Source: Compiled from Taylor, 2004: 259, 279, 284; Christopher, 2005: 57; Fawcett et al., 2007: 20) 


\section{Phase one of SCD: Understanding and meeting the needs of end customers}

As already mentioned, end customer demand for the product activates the flows in the supply chain (Taylor, 2004: 26), which accentuates the need for organisations to understand their markets' demands for their products. The supply chain's end customer is the person at the end of the supply chain who makes the decision whether or not to buy the product or service offered by the supply chain (Harrison, 2001: 1). The customer is the ultimate judge of the supply chain's performance. For this reason, it is essential to align the supply chain to the demands of its end customers (McCullen, Saw, Christopher \& Towill, 2006: 14; Jeong \& Hong, 2007: 578). Demand refers to the overall market demand for a group of related products (Hugos, 2006: 16). In today's competitive environment organisations are moving towards a more effective demand-driven supply chain to enable them to respond quickly to shifting customer requirements (Wisner, Tan \& Leong, 2009: 139). Therefore, understanding the market and the value that customers seek is a critical aspect of designing an effective supply chain strategy (Tang \& Gattorna, 2003: 29; Christopher, 2005: 57; Saxton, 2006: 59). It is clear that the end customer should be the starting point of any supply chain's design (Christopher, 2005: 56).

Effective supply chains have to be developed with respect to the product that is going to be supplied through the supply chain (Selldin \& Olhager, 2007: 42). Depending on the range of customers served by the organisation and its supply chains, there will be a range of products desired, along with the various quantities and delivery needs, product availability and response time needs, product quality demanded and prices that customers are willing to pay (Hines, 2004: 58; Wisner et al., 2005: 435; Hugos, 2006: 33, 34; Chopra \& Meindl, 2007: 26). For this reason, organisations must understand the nature of their products and be able to devise a supply chain strategy that best fits their customers' needs or demands by also taking into account the associated demand uncertainties. If products are classified according to their demand patterns in terms of characteristics such as life cycle length, demand predictability, product variety and market standards for lead time and service (Fisher, 1997: 1; Seuring, 2003: 183; Selldin \& Olhager, 2007: 43), they fall into one of two clearly distinguishable categories, namely primarily functional or primarily innovative products. Each category requires a distinct kind of supply chain (Fisher, 1997: 1, 2), as discussed below.

\section{Functional products}

Functional products satisfy the basic needs of customers. These needs do not change much over time. This means that the demand for these products is stable and predictable, which makes market mediation easy because a nearly perfect match between supply and demand can be achieved. Because of predictable demand, stockout costs and markdowns are low (Fisher, 1997: 2, 3; Lee, 2002: 106; Hines, 2004: 60; Chopra \& Meindl, 2007: 28). Functional products have longer life cycles and would likely be in mature or decline phases of the 
product life cycle model (Lee, 2002: 106; Appelqvist, 2003: 199; Seuring, 2003: 183; Ayers, 2006: 62). Since competition is fierce, profit margins tend to be low (Lee, 2002: 106; Ayers, 2006: 61; Chopra \& Meindl, 2007: 28). Examples of functional products include the staples that customers buy in a wide range of retail outlets such as grocery stores and fuel stations (Fisher, 1997: 2, 3).

\section{Innovative products}

Customers also have a need for innovative products. Supply chains will introduce innovations to try to gain competitive advantage by means of differentiation (Ayers, 2004: 44, 45). Innovative products are new or modified products organisations create to achieve higher margins (Raturi \& Evans, 2005: 208). They are characterised by high changes in demand over short times, which means that demand is volatile and difficult to forecast, which in turn increases demand uncertainty (Lee, 2002: 106; Seuring, 2003: 183; Taylor, 2004: 207). Innovative products are therefore also characterised by short life cycles and they have high profit margins (Fisher, 1997: 2; Lee, 2002: 106; Seuring, 2003: 183). Products will tend to be innovative during the introduction and growth phases of a product's product life cycle (Ayers, 2006: 64). They are the hardest products to manage (Taylor, 2004: 267).

Therefore, in determining the nature of the needs of the supply chain's end customers, organisations must determine whether the nature of the products that will satisfy these needs are functional or innovative (Fisher, 1997: 4). The differences between functional and innovative products are summarised in Table I.

Table I: Some basic differences between innovative and functional products

\begin{tabular}{|l|l|l|}
\hline & Functional products & Innovative products \\
\hline Demand & Stable, predictable & Variable, difficult to forecast \\
\hline Length of product life cycle & Long & Short \\
\hline Profitability & Low & High \\
\hline Forecast error & Low & High \\
\hline Stock-out rates & Low & High \\
\hline Markdown & Low & Potentially high \\
\hline Obsolescence & Low & High \\
\hline Volume & High & Low \\
\hline Lead time & Long & Short \\
\hline Inventory cost & Low & High \\
\hline Product variety & Low & High \\
\hline End result: Demand uncertainty & Low & High \\
\hline
\end{tabular}

(Source: Compiled from Fisher, 1997: 1, 2; Ayers, 2006: 63; Jacobs \& Chase, 2008: 186) 
From this discussion it can be concluded that functional and innovative products require fundamentally different supply chains (Ayers, 2006: 62). Sadler (2007: 179) confirms this by stating that supply chains operate most effectively if they have been designed for specific products for the supply chain's end customers. A supply chain cannot respond to all customers' demands in the same manner. In order to design the supply chain appropriately trade-offs have to be made (Seuring, 2003: 184). This also emphasises the need to understand the end customers' needs.

\section{Determining a value proposition to meet customers' needs}

Understanding customers will provide the inputs necessary for designing value propositions to meet and exceed customers' needs and expectations (Harrison, 2001: 2; Fawcett et al., 2007: 38). A value proposition is a statement of how, where and when value is to be created for specific customers. The value proposition should form the guiding principles around which all the activities of the organisation are based (Christopher, 2004: 32). This programme of products, services, ideas and solutions that an organisation offers its customers is the reason why customers will choose it over other alternatives (Hutt \& Speh, 2004: 7; Plantes \& Finfrock, 2009: 5). The value proposition must thus be defined from the customer's viewpoint (Christopher, 2004: 32; Plantes \& Finfrock, 2009: 73) and will require specific market winners that differentiate an organisation's products from those of their competitors. Generally, market winners can be either low cost or high service levels (MasonJones, Naylor \& Towill, 2000: 4064; Bozarth \& Handfield, 2006: 31).

Value is created when core competencies (or capabilities) are built (Fawcett et al., 2007: 81). Therefore, to develop a value proposition, organisations must know what their core competencies are (Reid \& Sanders, 2007: 33). As already mentioned, competencies are the skills and processes that are developed to create a value proposition, which in turn is the value an organisation promises to deliver to its end customers (Fawcett et al., 2007: 81). A core competency is defined as a bundle of skills and capabilities that enable an organisation to provide a particular benefit to customers (Hines, 2004: 49; Hutt \& Speh, 2004: 176). Core competencies differentiate an organisation or supply chain from its competitors, thus leading to a competitive advantage (Saunders, 1997: 103; Hines, 2004: 51; Fawcett et al., 2007: 81).

The first five key questions to be answered in the SCD analysis of organisations can thus be identified from the first phase of SCD. These questions are:

- Who are the organisation's end customers and what are the exact needs of the end customers?

- What are the market winners that will win end customers' orders?

- Does the organisation have a value proposition that will meet the needs of the end customers? 
- Does the organisation possess the necessary core competencies to provide the necessary value proposition?

- How predictable is the market demand for the product?

\section{Phase two of SCD: Selecting a supply chain strategy}

Once organisations understand the nature of their end customers' needs and have determined the value proposition necessary to meet these needs based on their core competencies and market winners, they can select a supply chain strategy (Christopher, 2004: 32; Taylor, 2004: 279; Raturi \& Evans, 2005: 207). A supply chain strategy can be defined as a strategy required to manage the integration of all the supply chain activities through improved supply chain relationships in order to achieve a competitive advantage for the supply chain (Hines, 2004: 5). The strategy needs to be developed to meet specific needs of its customers because supply chain strategies are market-driven (Ross, 1998: 12; Lee, 2002: 105; Hines, 2004: 119, 123). It starts with the business value proposition to customers, based on core competencies and identified market winners, and shows how the supply chain can contribute to achieving business goals by aligning the needs of the supply chain's customers and the supply chain's capabilities (Tang \& Gattorna, 2003: 25, 26; Chopra \& Meindl, 2007: 26). Since organisations often have products with different levels of uncertainty, managers should follow different supply chain strategies for different products (Croxton, Lambert, Garcia-Dastugue \& Rogers, 2006: 66).

Supply chain strategies are as varied as the disciplines from which they originate. Their intent is however consistent, namely to reduce uncertainties and costs while satisfying end customers' needs (Boone, Craighead \& Hanna, 2007: 594). Supply chain strategies may be designed to be more efficient and/or to be more effective (Hines, 2004: 378, 379). Within these parameters supply chains can be grouped into two broad categories that summarise their capabilities in meeting their end customers' needs. These two types of supply chains are efficient and responsive supply chains (Raturi \& Evans, 2005: 208; Chopra \& Meindl, 2007: 31). According to Christopher (2003: 284) an efficient supply chain is also known as a 'lean' supply chain and an effective, responsive supply chain as an 'agile' supply chain. If customers want more mature (or functional) products, the organisation will need to be able to provide stable sales. The supply chain will therefore be less responsive and more efficient. A product with a stable demand and a reliable source of supply should not be managed in the same way as one with a highly unpredictable demand and/or unreliable source of supply. If customers want innovative products, the organisation needs a more responsive supply chain to cope with demand uncertainties associated with such products (Lee, 2002: 105).

\section{Efficient (or lean) supply chains}

An efficient (or lean) supply chain is a set of organisations directly linked by flows of information, products and finances that work collaboratively to reduce cost and waste 
(Vitasek, Manrodt \& Abbott, 2005: 40). Efficient supply chains utilise strategies aimed at creating the highest cost efficiencies in the supply chain. For such efficiencies to be achieved, non-value-added activities should be eliminated, scale economies should be pursued and optimisation techniques should be deployed to get the best capacity utilisation in production and distribution (Lee, 2002: 113; Jacobs \& Chase, 2008: 187).

Lean supply chains are thus appropriate for and match functional products with high demand and high supply certainties where demand can be predicted and stable processes are operated efficiently to achieve economies of scale (Fisher, 1997; Seuring, 2003: 184; Bruce, Daly \& Towers, 2004: 154).

\section{Responsive (or agile) supply chains}

The idea of agility in the context of SCM focuses on responsiveness and flexibility (Christopher, 2003: 284; Christopher, Lowsen \& Peck, 2004: 369; Ismail \& Sharifi, 2006: 433). Agile supply chains utilise strategies aimed at being responsive to customer needs as well as flexible (Lee, 2002: 114; Jacobs \& Chase, 2008: 188). Supply chains where demand and supply uncertainties exist require agility (Towill \& Christopher, 2002: 301; Seuring, 2003: 184; Ayers, 2004: 46; Jacobs \& Chase, 2008: 187). The focus of agile supply chains is on time compression and quick response and on eliminating the barriers to quick response (Christopher, 2003: 283, 287).

Supply chain agility is the ability of the supply chain as a whole to rapidly align the network and its operations to the dynamic and turbulent requirements of customers' demands (Ismail \& Sharifi, 2006: 431). This agility enables an organisation to react quickly and more effectively to marketplace volatility and other uncertainties, thereby allowing the organisation to establish a superior competitive position (Swafford, Ghosh \& Murthy, 2005: 171). Agile supply chains are thus relevant for innovative products where demand is unpredictable (Bruce et al., 2004: 154; Swafford et al., 2005: 171). Table II provides a summary of the characteristics of lean and agile supply chains.

Table II: Some characteristics of lean and agile supply chains

\begin{tabular}{|l|l|l|}
\hline & Lean supply chain strategy & Agile supply chain strategy \\
\hline Product features & Standard & High variety \\
\hline Product life cycle & Long & Short \\
\hline Marketplace demand & Predictable & Volatile \\
\hline Product variety & Low & High \\
\hline Order winners & Cost & Time, availability \\
\hline Supply chain emphasis & Efficiency; economies of scale & Responsiveness, flexibility \\
\hline
\end{tabular}

(Source: Adapted from Christopher, 2003: 285; Bruce, et al., 2004: 155; Hines, 2004: 63; Chopra \& Meindl, 2007: 35; Webster, 2008: 352) 


\section{A combination of lean and agile supply chains}

Thus far, lean and agile supply chains have been discussed as trade-offs of each other. These supply chains have been discussed as if they are mutually exclusive and represent conflicting interests. However, in reality these two approaches can complement each other and in many cases a hybrid strategy is adopted where both lean and agile supply chains are utilised. This is possible because it is the supply chains that compete and not organisations (Towill \& Christopher, 2002: 299, 300). Hybrid (or 'leagile') supply chains exploit the benefits of both lean and agile supply chains (Towill \& Christopher, 2002: 300). Leagile supply chains thus use a combination of lean and agile approaches within a supply chain strategy (MasonJones et al., 2000: 4065).

Supply chains that utilise both lean and agile supply chain strategies will have a certain point in their supply chain where organisations will switch from managing the supply chain using one strategy to managing the supply chain using another strategy (Simchi-Levi, Kaminsky \& Simchi-Levi, 2003: 122). This point is termed the decoupling point. The decoupling point is the point at which real demand penetrates upstream in a supply chain. The decoupling point is also termed the push-pull boundary (Christopher, 2003: 288). In fact, push-pull boundaries refer to the positioning of decoupling points in the supply chain (Goldsby \& Garcia-Dastugue, 2006: 104). The decoupling point is thus the point in the product flow stream to which the customer's order penetrates and where real time data and forecastdriven activities meet (Mason-Jones et al., 2000: 4061). The decoupling point is an important choice in any supply chain design (Fleischmann, Van Nunen, Gräve \& Gapp, 2005: 181). The decoupling point confirms that the real focus of supply chain re-engineering should be on seeking ways in which organisations can achieve the appropriate combination of lean and agile strategies (Christopher, 2003: 291). Leagile supply chains require the selection and setting up of a decoupling point (Towill \& Christopher, 2002: 300; Bruce et al., 2004: 154).

When the supply chain faces a highly volatile demand from the customer to the decoupling point, it should be agile (Appelqvist, 2003: 201). Therefore, downstream (customer-side) of the decoupling point the processes are designed to be agile to make provision for the more unpredictable marketplace (Mason-Jones et al., 2000: 4065; Towill \& Christopher, 2002: 300; Lysons \& Farrington, 2006: 146). The flow of products should therefore be marketdriven (Christopher, 2003: 289; Lysons \& Farrington, 2006: 146). End customers' needs trigger demand and this demand 'pulls' the required products through the supply chain (Waller, 2003: 460).

Upstream (supplier-side) of this decoupling point, the processes are designed to be lean, enabling a level schedule and opportunities to reduce costs (Mason-Jones et al., 2000: 4065; Towill \& Christopher, 2002: 300; Appelqvist, 2003: 201). Upstream organisations work to a stable demand with relatively low variety and can therefore focus on lean low-cost 
manufacture (Lysons \& Farrington, 2006: 146). Risk can thus be reduced by delaying for as long as possible the time at which the decision must be taken to make a specific product available in a specific place (Tellarini, Pellandini, Battezzati, Fascina \& Ferrozzi, 2007: 190). Therefore the flow of products upstream from the decoupling point may well be forecastdriven (Christopher, 2003: 289; Lysons \& Farrington, 2006: 146). In the upstream supply chain, products are thus pushed through the supply chain and are stored in anticipation of demand (Waller, 2003: 460; Reid \& Sanders, 2007: 228). In a push-based system, production and distribution decisions are based on long-term forecasts. Demand forecasts are based on orders received from downstream supply chain partners (Simchi-Levi et al., 2003: 121). Inventory is thus produced in advance of demand and 'pushed' down the supply chain towards the customer towards points of sale where they are stored as finished goods inventory (Taylor, 2004: 341; Evans \& Collier, 2007: 370), as illustrated in Figure 2.

\section{Decoupling point (or push-pull boundary)}

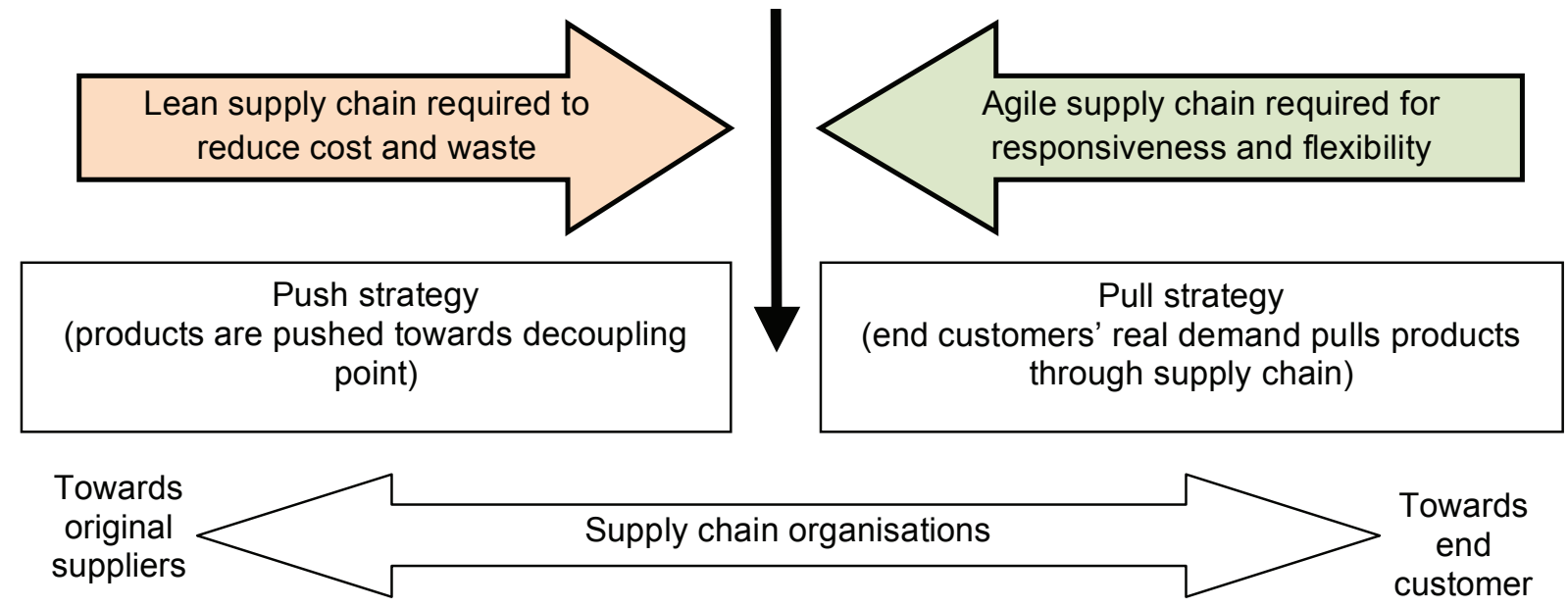

Figure 2: The decoupling point (or push-pull boundary)

(Source: Adapted from Christopher, 2003: 290; Simchi-Levi et al., 2003: 123;

Taylor, 2004: 30, 341)

Thus, with the leagile strategy the decoupling point must be positioned so that the supply chain can respond to volatile downstream customer demand with, for example, high service levels, while still maintaining lean objectives such as cost-effectiveness (Mason-Jones et al., 2000: 4065; Bruce et al., 2004: 155). Agile supply chains account for high service levels while lean supply chains account for cost-effectiveness. The critical questions of SCD that can be identified from the discussion of phase two of SCD are:

- What is the organisation's position in terms of the decoupling point?

- Which supply chain strategy should be adopted by the organisation?

\section{Phase three of SCD: Scoping the supply chain structure}

The term 'supply chain structure' refers to the sequential links among supply chain activities (Appelqvist, Lehtonen \& Kakkonen, 2004: 676). The supply chain structure must support the 
supply chain strategy (Defee \& Stank, 2005: 34). Once organisations have decided on a core supply chain strategy, they need to determine the scope of the design effort. The supply chain scope embodies the configuration of the supply chain's structure, processes and operations (Taylor, 2004: 284). Organisations have to identify the supply chain partners with whom they would want to build collaborative relationships through supply chain integration (Taylor, 2004: 284; Raturi \& Evans, 2005: 208). The supply chain structure thus implies the integration of the links between supply chain members (Defee \& Stank, 2005: 34).

\section{Supply chain partners}

Specific supply chain partners who can contribute best to the value proposition must be identified (Taylor, 2004: 284; Raturi \& Evans, 2005: 208). An important part of SCD is thus to decide which type of partnership is most appropriate for a particular relationship (Sadler, 2007: 170). Specific roles and responsibilities of individual supply chain members can then be defined (Fawcett et al., 2007: 335). However, it is highly unlikely that all links will be integrated and managed throughout the entire supply chain. Some members or links are less important in supply chains and do not justify attention and integration during supply chain design. Some links are more critical than others and need to be integrated and managed (Lambert, 2006: 15).

Collaboration built on trust between these supply chain members is essential. Identifying and collaborating with only the critical primary supply chain members (which can be beyond tier one) allows an organisation to share relevant information and to concentrate its time and resources on managing the important process links, enabling the supply chain to perform well (Handfield \& Nichols, 1999: 43; Hines, 2004: 187; Wisner et al., 2005: 411; Lambert, 2006: 15, 357). Collaboration thus comprises closely integrated, mutually beneficial relationships that enhance supply chain performance (Lambert et al., 2006: 169). The closer the relationship between buyer and supplier the more likely it is that the expertise of both parties can be applied to mutual benefit (Christopher, 2005: 201).

\section{Supply chain drivers}

Managing supply chain drivers is also an important aspect of SCD (Rafele, 2004: 281; Raturi \& Evans, 2005: 203). In any supply chain there are drivers that determine the performance of the supply chain (Chopra \& Meindl, 2007: 51). To determine the drivers in a supply chain the supply chain needs to be broken up into simple components. In doing so, it can be seen that a supply chain is basically a set of facilities connected by transportation lanes in which inventories (products) are moved towards end customers between various supply chain members based on information and finance flows (Taylor, 2004: 21, 24). Six supply chain drivers, namely facilities, inventory, transportation, information, sourcing and pricing, are identified. These drivers interact with each other (Chopra \& Meindl, 2007: 51). Supply chain drivers thus have an impact on the supply chain's capabilities of responsiveness and 
efficiency (Hugos, 2006: 37). The interrelationship between the supply chain drivers and their effect on efficiency and responsiveness are illustrated in Figure 3.

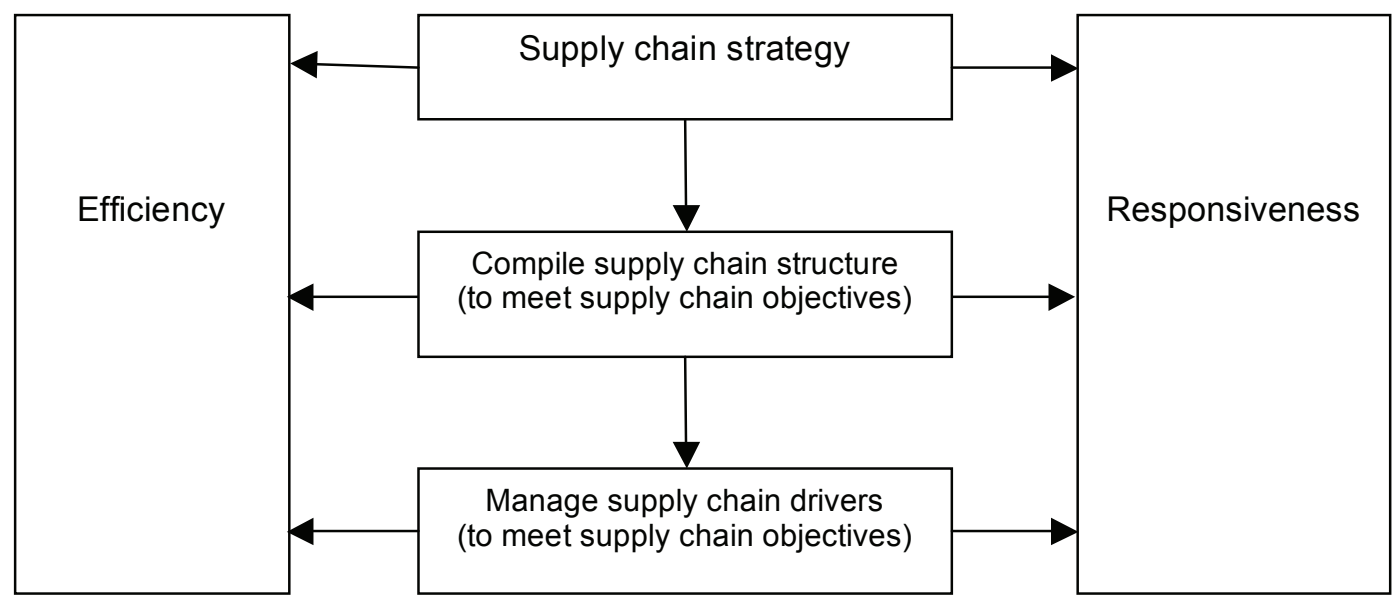

Figure 3: The relation of supply chain drivers towards supply chain strategy

(Source: Derived from Chopra \& Meindl, 2007: 47)

\section{Facilities}

Production refers to the capacity of a supply chain to make and store products (Hugos, 2006: 10). The capacity where production takes place is referred to as facilities. Decisions regarding the facilities (and their locations) owned and operated by organisations and their relationships with other supply chain members are important elements of SCD (Shapiro, 2007: 325; Jacobs \& Chase, 2008: 206). Decisions regarding the role, location, capacity and flexibility of facilities have a significant impact on the supply chain's performance, and there are certain trade-offs between responsiveness and efficiency that have to be made concerning facilities. Decentralised factories and warehouses with a lot of excess capacity are flexible and can respond quickly to fluctuations in demand (albeit with increased costs) whereas centralised facilities with little excess capacity cannot do so (Chopra \& Meindl, 2007: 44; Hugos, 2006: 10). Facilities working at full capacity cannot always be flexible and agile (Waters, 2007: 205).

\section{Inventory}

Facilities contain controlled quantities of materials called inventories (Taylor, 2004: 22). The inventory is the stock of any item or resource used in an organisation (Jacobs \& Chase, 2008: 312). Organisations also need to make decisions about the inventory with regard to responsiveness and efficiency (Hugos, 2006: 12). Responsiveness is enhanced with a wide range of products to satisfy customer demand. However, in increasing the inventory the organisation increases its costs, thereby making it less efficient. Reducing the inventory makes the organisation more efficient but less responsive (Hugos, 2006: 12, 35; Chopra \& Meindl, 2007: 45). 


\section{Transportation}

Transportation entails moving inventory from point to point between the facilities of supply chain members in the supply chain. Transportation can take the form of many combinations of modes and routes, each with its own performance characteristics (Chopra \& Meindl, 2007: 45). Transportation typically supports the inbound, internal and outbound linkages throughout a supply chain (Monczka et al., 2005: 549). Externally (inbound and outbound), it satisfies customers' needs and expectations and internally, transportation leads to efficiency in supply chain performance, enabling the organisation to operate with lower inventory levels at lower cost (Raturi \& Evans, 2005: 220). Responsiveness is enhanced by fast and flexible but more expensive transport modes, while efficiency can be increased by transporting products in larger batches and doing it less often (Bozarth \& Handfield, 2006: 342; Hugos, 2006: 36; Chopra \& Meindl, 2007: 45;). This, however, will result in increased inventory levels through the supply chain (Bozarth \& Handfield, 2006: 349).

\section{Information}

Organisations need information about all elements within the supply chain (Raturi \& Evans, 2005: 221). Information as a supply chain driver thus consists of data and analysis of facilities, inventory, transportation, costs, prices, customer demand and suppliers throughout the supply chain (Raturi \& Evans, 2005: 221; Chopra \& Meindl, 2007: 45). The trade-off between responsiveness and efficiency involves weighing the benefits of obtaining good information against the cost of acquiring it. High levels of responsiveness can be achieved when organisations collect and share accurate and timely data generated by the other supply chain drivers (Hugos, 2006: 16, 37, 38).

\section{Sourcing}

Sourcing decisions affect both the responsiveness and the efficiency of a supply chain. Sourcing certain processes to other parties may increase a supply chain's efficiency, but may reduce its responsiveness due to possible longer lead times (Chopra \& Meindl, 2007: 45). On the other hand, responsiveness can be increased by, for example, gaining access to state-of-the art products (Bozarth \& Handfield, 2006: 298).

\section{Pricing}

Pricing determines how much an organisation will charge for products that it makes available in the supply chain. Pricing affects the behaviour of the buyer of the product, thus affecting supply chain performance (Chopra \& Meindl, 2007: 45). Customers who value responsiveness will pay more for higher levels of customer service.

\section{Supply chain key performance indicators}

Establishing the right supply chain KPIs is also an important aspect of SCD (Rafele, 2004: 281; Raturi \& Evans, 2005: 203). Implementing a supply chain strategy requires KPls that 
align performance with the objectives of other supply chain members (Lambert \& Pohlen, 2006: 204). The selected KPIs to measure supply chain performance measurement should be able to translate the supply chain strategy (Wang, Heng \& Chau, 2007: 333). Supply chain trading partners must adopt specific measures to ensure that performance and supply chain objectives are aligned (Wisner, Tan \& Leong, 2009: 488). Agile supply chains should adopt KPls that focus primarily on service levels (and availability) and lean supply chains should use KPIs that focus primarily on cost (Christopher \& Towill, 2001: 237; Agarwal \& Shankar, 2002: 32), while leagile supply chains focus on the benefits of both lean and agile supply chains (Towill \& Christopher, 2002: 300).

From the discussion of the third phase of SCD, three key questions can be identified are:

- Who are the critical supply chain members that the organisation needs to collaborate with and are these relationships being managed?

- How should the supply chain drivers be managed to be in line with the organisation's supply chain strategy?

- Which supply chain KPls should the organisation focus on?

This concludes the discussion on the elements of SCD across three broad phases of SCD. By knowing what these elements entail organisations are able to critically analyse their supply chain practices around these elements. This can be done by answering the basic questions about their SCD as indicated in the various sections above.

\section{THE DEVELOPMENT OF A CONCEPTUAL FRAMEWORK}

In the previous sections several critical questions were identified from the various phases of SCD. These critical questions were used to develop a conceptual framework with which organisations can analyse their SCD practices and determine whether their SCD practices are in line with their organisational objectives. The conceptual framework is illustrated in Figure 4. 


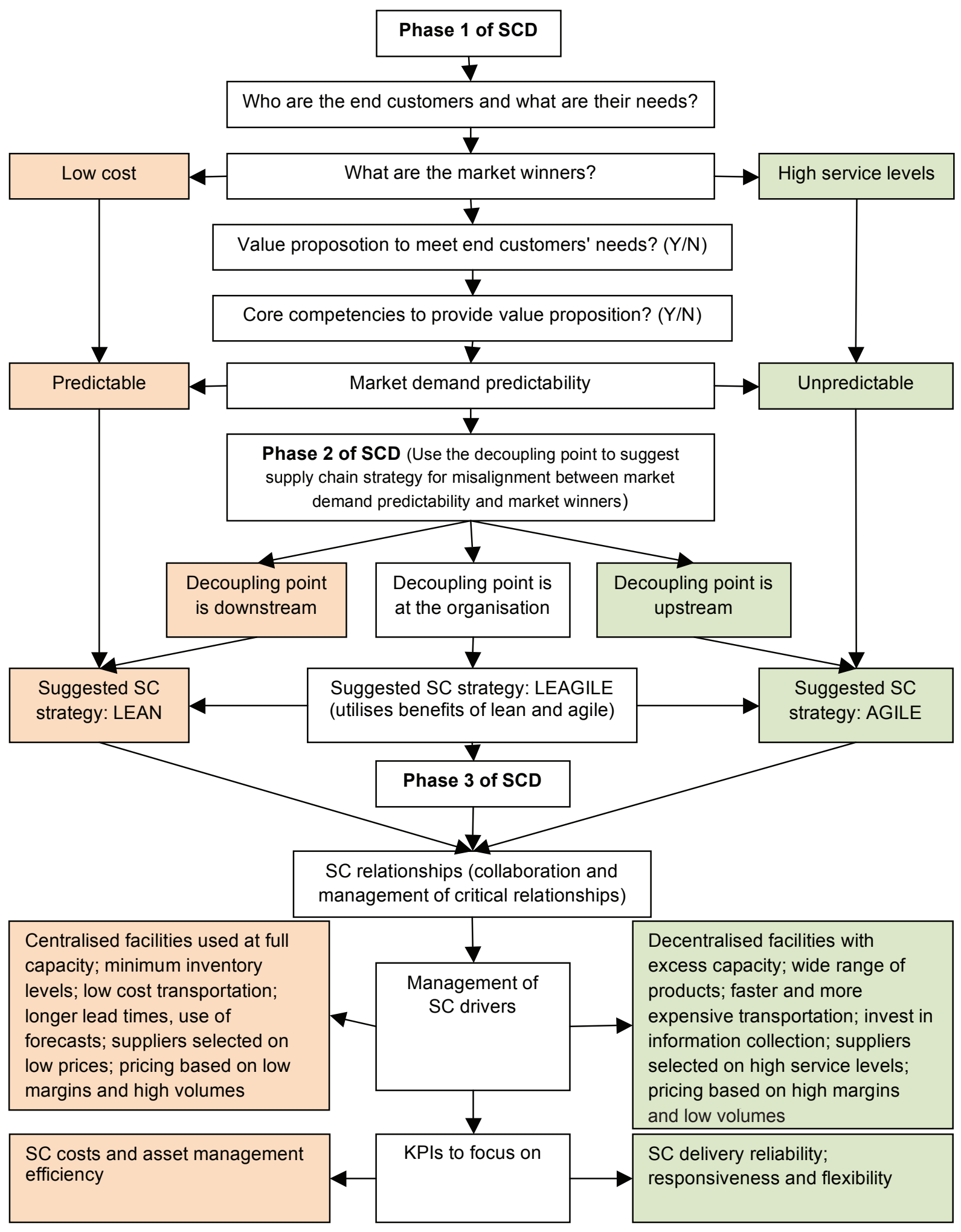

Figure 4: The conceptual framework to analyse SCD practices

From Figure 4 it can be seen that organisations have to know who their end customers are and what the needs of their end customers are. Organisations that have low cost as a market winner and have a predictable market demand should use a lean supply chain strategy. On the other hand, organisations who have high service levels as a market winner and who have 
an unpredictable market demand should use an agile supply chain strategy. Organisations then have to establish whether they have a value proposition and core competencies to meet the needs of their end customers. Organisations will then collaborate with critical supply chain members who pursue the same strategy as them (i.e. either lean or agile). Lean supply chains should manage their supply chain drivers according to lean principles and agile supply chains should manage their supply chain drivers according to agile principles. Similarly, lean supply chains should focus on KPIs that measure costs and asset management efficiency, while agile supply chains should focus on KPls that measure supply chain delivery reliability, responsiveness and flexibility. This is highlighted in Figure 4. Alignment for lean supply chains is indicated in red (on the left-hand side of Figure 4) while alignment for agile supply chains is indicated in green (on the right-hand side of Figure 4).

Leagile supply chains utilise the benefits of both lean and agile supply chains. The decoupling point for lean supply chains is usually downstream and for agile supply chains it is upstream. The position of the organisation in terms of the decoupling point will be used to suggest a supply chain strategy if there is misalignment between an organisation's market demand predictability and their market winners. In these cases, a lean supply chain strategy will be suggested for organisations upstream from the decoupling point, while an agile supply chain strategy will be suggested to organisations downstream from the decoupling point. Leagile supply chain strategies are suggested if the organisation is positioned at the decoupling point. With leagile supply chains organisations will have to evaluate their supply chain relationships, drivers and KPIs to determine whether it is managed optimally.

\section{TESTING THE CONCEPTUAL FRAMEWORK}

The conceptual framework was tested in two South African organisations. One organisation was in the retail sector and the other was in the manufacturing sector. For confidentiality purposes these organisations will be referred to as organisations $A$ and B. Organisation $A$ is in the manufacturing industry and organisation $B$ is in the retail sector.

Organisation A knew who its end customers were and what the needs of its end customers were. The organisation was also of the opinion that it had a value proposition and core competencies to meet its end customers' needs. Organisation A's market demand was predictable and its market winner was low cost. A lean supply chain strategy was thus followed by organisation A. Organisation A was managing its supply chain relationships with its first tier supplier and customers well, but was struggling with its second tier customers. Organisation A can thus explore options to see where they could possibly improve these relationships. Organisation A was managing most of its supply chain drivers according to a lean supply chain strategy. However, they used decentralised facilities (in contrast to what the literature suggests for a lean supply strategy). Organisation A may explore the 
possibility of centralising more of its facilities. To conclude, organisation A was focusing on KPIs that were internal measures. They were using internal cost measures to measure their performance. They should rather focus on KPls that measure total supply chain costs across the supply chain as well as on KPls that measure how they are managing their assets. They were not focusing on these KPls according to the conceptual framework.

Organisation B also knew who their end customers were and how they could meet the needs of these customers. They also had a value proposition and possessed core competencies to meet these needs. Organisation B's market winner was high service levels and their market demand was unpredictable. They therefore follow an agile supply chain strategy. Organisation B was only collaborating with its first tier suppliers and customers. Being in the retail sector, they need to investigate the possibility of collaborating with strategic second tier suppliers as well. Organisation B was managing some of its supply chain drivers according to an agile supply chain strategy. However, it used centralised facilities, was minimising its inventory levels, was using long lead times and was using low cost transportation to manage its supply chain flows. This is in contrast with what the literature suggests. Organisation B was also using low margins and high volumes as its pricing policy. These issues need to be explored to see whether in fact organisation B needs to manage these drivers more responsively. For example, with long lead times and slow cheaper modes of transport they may be losing out on sales due to the agile demands of their customers. By minimising their inventory levels they may also be in danger of not being able to meet the flexible needs of their customers. Organisation B was focusing on the correct KPIs.

\section{CONCLUSIONS AND RECOMMENDATIONS}

SCD comprises three phases:

1) Organisations must understand the needs of their end customers and determine how to meet these needs with a value proposition based on core competencies and market winners.

2) Organisations have to select a supply chain strategy.

3) Organisations need to scope their supply chain structure.

It is imperative that organisations align the various phases of their SCD with each other because ultimately organisations have to satisfy the needs of their end customers. The needs of end customers can be grouped into needs for either functional or innovative products. Organisations also have to establish whether they have the core competencies to provide the necessary value proposition based on certain market winners. Functional products require lean (or efficient) supply chains while innovative products require agile (or responsive) supply chains. Some supply chains will use both a lean and an agile supply chain. This supply chain is referred to as a leagile (or hybrid) supply chain. In a leagile 
supply chain it is necessary to determine exactly where the decoupling point (or push-pull boundary) is, because it is at this point where the supply chain switches from implementing a lean strategy to an agile strategy.

Scoping the supply chain structure entails three broad issues. First, it entails selecting and collaborating with the right supply chain members (and assigning roles and responsibilities to the critical or important members across various supply chain processes). Secondly, it looks at the supply chain drivers and how these drivers should be utilised. Six supply chain drivers have been identified. These drivers are facilities, inventory, transport, information, sourcing and pricing. On the one hand, organisations will use their supply chain drivers to achieve efficiency if they implement a lean supply chain strategy. On the other hand, organisations will use their supply chain drivers to achieve responsiveness if the organisations have an agile supply chain strategy. Thirdly, scoping the supply chain structure also embodies the establishment of supply chain KPIs. Lean supply chain strategies will emphasise cost-related KPIs while agile supply chains will emphasise service-related KPIs.

The conceptual framework was tested in two organisations and proved to be a useful instrument. Some useful points were raised in the assessment of these two organisations' SCD practices. Answering these questions and using the conceptual framework will provide organisations with a sound point of departure to be able to analyse and adapt the designs of their supply chains. It should indicate whether their supply chain management efforts are aligned with their organisational objectives to meet the needs of their customers. Effective SCD leads to improved supply chain integration, which in turn leads to improved supply chain performance. In answering these critical questions about their SCD (and ensuring alignment between the three phases of SCD), organisations will certainly ensure that they are improving their efforts to improve the performance of their supply chain. 


\section{REFERENCES}

Agarwal, A. \& Shankar, R. 2002. Analysing alternatives for improvement in supply chain performance. Work Study, 51(1): 32-37.

Appelqvist, P. 2003. Order winners, order qualifiers and supply chain strategies- a comparison. In Seuring, S., Müller, M., Goldbach, M. \& Schneidewind, U. (eds). Strategy and organisation in supply chains: 181-196. Heidelberg, Germany: Physica-Verlag.

Appelqvist, P., Lehtonen, J-M. \& Kakkonen, J. 2004. Modelling in product and supply chain design: literature survey and case study. Journal of Manufacturing Technology Management, 15(7): 675-86.

Ayers, J. B. 2004. Supply chain project management: a structured collaborative and measurable approach. Boca Raton, Florida: St. Lucie Press.

Ayers, J. B. 2006. Handbook of supply chain management. Boca Raton, Fl: Auerbach publications.

Baily, P., Farmer, D., Crocker, B, Jessop, D. \& Jones, D. 2009. Purchasing principles and management. Harlow, England: Prentice Hall.

Boone, C. A., Craighead, C. W. \& Hanna, J. B. 2007. Postponement: an evolving supply chain concept. International Journal of Physical Distribution and Logistics Management, 37(8): 594-611.

Bozarth, C. C. \& Handfield, R. B. 2006. Introduction to operations and supply chain management. Upper Saddle River, New Jersey: Pearson Prentice Hall.

Bruce, M., Daly, L. \& Towers, N. 2004. Lean or agile: a solution for supply chain management in the textiles and clothing industry? International Journal of Operations and Production Management, 24(2): 151-70.

Burt, D. N., Dobler, D. W. \& Starling, S. L. 2003. World class supply management: the key to supply chain management. McGraw-Hill: Boston.

Cagliano, R., Caniato, F. \& Spina, G. 2006. The linkage between supply chain integration and manufacturing improvement programmes. International Journal of Operations and Production Management, 26(3): 282-99.

Chopra, S. \& Meindl, P. 2007. Supply chain management: strategy, planning and operation. Upper Saddle River, New Jersey: Pearson 
Christopher, M. 2003. Creating agile supply chains. In Gattorna, J. L. (ed). Gower handbook of supply chain management, 283-295. Burlington, VT: Gower.

Christopher, M. 2004. Supply chains: a marketing perspective. In New, S. \& Westbrook, R. (eds). Understanding supply chains: concepts, critiques and futures, 23-42. New York: Oxford University press.

Christopher, M. 2005. Logistics and supply chain management: creating value-adding networks. Harlow, England: Prentice Hall.

Christopher, M., Lowsen, R. \& Peck, H. 2004. Creating agile supply chains in the fashion industry. International Journal of Retail and Distribution Management, 32(8): 367-76.

Christopher, M. \& Towill, D. 2001. An integrated model for the design of agile supply chains. International Journal of Physical Distribution and Logistics Management, 31(4): 235-46.

Croxton, K. L., Lambert, D. M., García-Dastugue, S. J. \& Rogers, D. S. 2006. The demand management process. In Lambert, D. M. (ed). Supply chain management: processes, partnerships, performance, 59-76. Sarasota, Florida: Supply Chain Management Institute.

Defee, C. C. \& Stank, T. P. 2005. Applying the strategy-structure-performance paradigm to the supply chain environment. International Journal of Logistics Management, 16(1): 28-50.

Evans, J. R. \& Collier, D. A. 2007. Operations management: an integrated goods and services approach. Mason, $\mathrm{OH}$ : Thomson South Western.

Fabbe-Costes, N. \& Jahre, M. 2007. Supply chain integration improves performance: the emperor's new suit? International Journal of Physical Distribution and Logistics Management, 37(10): 835-55.

Fawcett, S. E., Ellram, L. M. \& Ogden, J. A. 2007. Supply chain management: from vision to implementation. Upper Saddle River, New Jersey: Prentice Hall.

Fisher, M. L. 1997. What is the right supply chain for your product? Harvard Business Review, March-April: 1-12.

Fleischmann, M., Van Nunen, J., Gräve, B. \& Gapp, R. 2005. Reverse logistics- capturing value in the extended supply chain. In An, C. \& Fromm, H. (eds). Supply chain management on demand: strategies technologies, applications, 167-186. Berlin Heidelberg: Springer

Gattorna, J. 2006. Living supply chains. Harlow, England: Prentice Hall. 
Goldsby, T. J. \& Garcia-Dastugue, S. J. 2006. The manufacturing flow management process. In Lambert, D. M. (ed). Supply chain management: processes, partnerships, performance, 93-114. Florida: Supply chain management institute.

Halldórsson, A., Kotzab, H., Mikkola, J. H. \& Skjǿtt-Larsen, T. 2005. How inter-organisational theories contribute to supply chain management. In De Koster, R. \& Delfmann, W. (eds). Supply Chain Management: European Perspectives, 37-61. Denmark: Copenhagen Business School Press.

Handfield, R. B. \& Nichols, E. L., (jr). 1999. Introduction to supply chain management. Upper Saddle River, New Jersey: Prentice Hall.

Handfield, R. B. \& Nichols, E. L. (jr). 2002. Supply chain redesign: transforming supply chains into integrated value systems. Upper Saddle River, NJ: Financial Times Prentice Hall.

Harrison, F. 2001. Supply chain management workbook. Woburn, MA: ButterworthHeinemann.

Hines, T. 2004. Supply chain strategies: customer-driven and customer-focused. Boston: Elsevier.

Hugo, W. M. J., Badenhorst-Weiss, J. A. \& Van Biljon, E. H. B. 2004. Supply Chain Management: logistics in perspective. Van Schaik: Pretoria.

Hugos, M. 2006. Essentials of supply chain management. Hoboken, New Jersey: John Wiley and Sons, Inc.

Hutt, M. D. \& Speh, T. W. 2004. Business marketing management: a strategic view of industrial and organisational markets. Mason, Ohio: Thomson South Western.

Ismail, H. S. \& Sharifi, H. 2006. A balanced approach to building agile supply chains. International Journal of Physical Distribution and Logistics Management, 36(6): 431-44.

Jacobs, F. R. \& Chase, R. B. 2008. Operations and supply management: the core. Boston: McGraw Hill.

Jacobs, F. R., Chase, R. B. \& Aquilano, N. J. 2009. Operations and supply management. New York: McGraw-Hill Irwin.

Jeong, J. S. \& Hong, P. 2007. Customer orientation and performance outcomes in supply chain management. Journal of Enterprise Information Management, 20(5): 578-94. 
Kim, S. W. 2006. The effect of supply chain integration on the alignment between corporate competitive capability and supply chain operational capability. International Journal of Operations and Production Management, 26(10): 1084-107.

Kumar, A., Ozdamar, L. \& Zhang, C. N. 2008. Supply chain redesign in the healthcare industry of Singapore. Supply Chain Management: An International Journal, 13(2): 95-103.

Lambert, D. M. 2006. Supply chain management. In Lambert, D. M. (ed). Supply chain management: processes, partnerships, performance, 1-24. Florida: Supply Chain Management Institute.

Lambert, D. M. \& Pohlen, T. L. 2006. Supply chain management performance measurement. In Lambert, D. M. (ed). Supply chain management: processes, partnerships, performance, 197-216. Florida: Supply Chain Management Institute.

Lee, H. L. 2002. Aligning supply chain strategies with product uncertainties. Available from http://66.102.1104/scholar?hl=en\&lr=\&q=cache:kgpfP7h9-soJ:home,sandiego.edu/ ... (accessed 17 Aug 2007).

Lysons, K. \& Farrington, B. 2006. Purchasing and supply chain management. Prentice HallFinancial Times: Harlow.

Magnan, G. M. \& Fawcett, S. E. 2006. Function and form in supply management organisations. In Cavinato, J. L., Flynn, A. E. \& Kauffman, R. G. (eds). The supply management handbook, 329-355. New York: McGraw Hill.

Mason-Jones, R., Naylor, B. \& Towill, D. R. 2000. Lean, agile or leagile? Matching your supply chain to the marketplace. International Journal of Production Research, 38(17): 4061-70.

Matopoulos, A., Vlachopoulou, M., Manthou, V. \& Manos, B. 2007. A conceptual framework for supply chain collaboration: empirical evidence from the agri-food industry. Supply Chain Management: An International Journal, 12(3): 177-86.

McCullen, P., Saw, R., Christopher, M. \& Towill, D. 2006. The F1 supply chain: adapting the car to the circuit- the supply chain to the market. Supply Chain Forum: An International Journal, 7(1): 14-23.

Mentzer, J. T. 2001. Supply chain management. Thousand Oaks, California: Sage.

Mentzer, J. T. 2004. Fundamentals of supply chain management: twelve drivers of competitive advantage. London: Sage. 
Monczka, R., Trent, R. \& Handfield, R. 2005. Purchasing and supply chain management. South Western: Mason, Ohio.

Moon, S-A. 2004. The relationships among manufacturer product strategy, supply chain structure and supply chain inventory. Asia Pacific Journal of Marketing and Logistics, 16(2): 20-45.

Nunlee, M., Qualls, W. \& Rosa, J. A. 2000. Antecedents of supply chain management: a performance measurement model. American Marketing Association Conference Proceedings, (11): 354-60. ABI/inform Global.

Pangburn, M. S. \& Stavrulaki, E. 2005. Service facility location and design with pricing and waiting-time considerations. In Geunes, J. \& Pardalos, P. M. (eds). Supply chain optimization, 209-241. New York: Springer.

Persson, F. \& Olhager, J. 2002. Performance simulation of supply chain designs. International Journal of Production Economics, (77): 231-45.

Plantes, M. K. \& Finfrock, R. D. 2009. Beyond price: differentiate your company in ways that really matter. Austin, TX: Greenleaf book group press.

Rafele, C. 2004. Logistics service measurement: a reference framework. Journal of Manufacturing Technology Management, 15(3): 280-290.

Raturi, A. S. \& Evans, J. R. 2005. Principles of operations management. Mason, Ohio: SouthWestern.

Reeve, J. M. \& Srinivasan, M. M. 2005. Which supply chain design is right for you? Supply Chain Management Review, May/June: 50-57.

Reid, R. D. \& Sanders, N. R. 2007. Operations management: an integrated approach. Hoboken, NJ: John Wiley and Sons, Inc.

Reiner, G. \& Trcka, M. 2003. Customized supply chain design: problems and alternatives for a production company in the food industry. A simulation-based analysis. International Journal of Production Economics, (89): 217-29.

Ross, D. F. 1998. Competing through supply chain management: creating market-winning strategies through supply chain partnerships. Chapman \& Hall: New York.

Sadler, I. 2007. Logistics and supply chain integration. London: Sage publications. 
Santoso, T., Ahmed, S., Goetschalckx, M. \& Shapiro, A. 2004. A stochastic programming approach for supply chain network design under uncertainty. European Journal of Operational Research, (167): 96-115.

Saunders, M. 1997. Strategic purchasing and supply chain management. London: Financial Times Pitman Publishing.

Saxton, B. M. 2006. Rock the boat. Bryanston: Terranova.

Selldin, E. \& Olhager, J. 2007. Linking products with supply chains: testing Fisher's model. Supply Chain Management: An International Journal, 12(1): 42-51.

Seuring, S. 2003. Strategic supply chain management- from focused factories to focused supply chains. In Seuring, S., Müller, M., Goldbach, M. \& Schneidewind, U. (eds). Strategy and organisation in supply chains, 181-196. Heidelberg, Germany: Physica-Verlag.

Sezen, B. 2008. Relative effects of design, integration and information sharing on supply chain performance. Supply Chain Management: An International Journal, 13(3): 233-40.

Shapiro, J. F. 2007. Modeling the supply chain. Belmont, CA: Thomson Higher Education.

Sharifi, H., Ismail, H. S. \& Reid, I. 2006. Achieving agility in supply chain through simultaneous 'design of' and 'design for' supply chain. Journal of Manufacturing Technology Management, 17(8): 1078-98.

Shen, Z-J. M. \& Daskin, M. S. 2005. Trade-offs between customer service and cost in integrated supply chain design. Manufacturing and Service Operations Management, $7(3)$ : 188-207.

Simchi-Levi, D., Kaminsky, P. \& Simchi-Levi, E. 2003. Designing and managing the supply chain: concepts, strategies, and case studies. Boston: McGraw-Hill.

Storey, J., Emberson, C., Godsell, J. \& Harrison, A. 2006. Supply chain management: theory, practice and future challenges. International Journal of Operations and Production Management, 26(7): 754-74.

Sundaram, R. M. \& Mehta, S. G. 2002. A comparative study of three different SCM approaches. International Journal of Physical Distribution and Logistics, 32(7): 532-55.

Swafford, P. M., Ghosh, S. \& Murthy, N. 2005. The antecedents of supply chain agility of a firm: scale development and model testing. Journal of Operations Management, (24): 170-88. 
Tang, M. \& Gattorna, J. L. 2003. Developing an aligned supply chain operating strategy. In Gattorna, J. L. (ed). Gower handbook of supply chain management, 25-35. Burlington, VT: Gower.

Taylor, D. A. 2004. Supply chains: a manager's guide. Boston: Addison-Wesley.

Tellarini, F., Pellandini, S., Battezzati, L., Fascina, G. \& Ferrozzi, C. 2007. Designing the supply chain. In Perret, F-L., Jaffeux, C., Fender, M. \& Wieser, P. (eds). Essentials of logistics and management, 173-205. Lausanne: EPFL press.

Towill, D. R. \& Christopher, M. 2002. The supply chain strategy conundrum: to be lean or agile or to be lean and agile. International Journal of Logistics: Research and Applications, 5(3): 299-309.

Vitasek, K., Manrodt, K. B. \& Abbott, J. 2005. What makes a lean supply chain? Supply Chain Management Review, 9(7): 39-45.

Waller, D. L. 2003. Operations management: a supply chain approach. London: Thomson.

Wang, W. Y. C., Heng, M. S. \& Chau, P. Y. K. 2007. Supply chain management: issues in the new era of collaboration and competition. London: Idea Group Publishing

Waters, D. 2003. Logistics: an introduction to supply chain management. London: Palgrave Macmillan.

Waters, D. 2007. Supply chain risk management: vulnerability and resilience in logistics. London: Kogan Page.

Wisner, J. D., Leong, G. K. \& Tan, K-C. 2005. Principles of supply chain management: a balanced approach. Mason, Ohio: South-Western

Wisner, J. D., Tan, K-C. \& Leong, G. K. 2009. Principles of supply chain management: a balanced approach. Mason, Ohio: South-Western Cengage Learning.

Zokaei, K. \& Hines, P. 2007. Achieving consumer focus in supply chains. International Journal of Physical Distribution and Logistics Management, 37(3): 223-47. 